\title{
Prolonged glucose infusion into conscious rats inhibits early steps in insulin signalling and induces translocation of GLUT4 and protein kinase $C$ in skeletal muscle
}

\author{
B.Houdali ${ }^{1}$, V.Nguyen ${ }^{2}$, H.P.T. Ammon ${ }^{2}$, M. Haap ${ }^{1}$, W. Schechinger ${ }^{1}$, F.Machicao ${ }^{1}$, K. Rett ${ }^{1}$, H-U.Häring ${ }^{1}$, \\ E.D.Schleicher ${ }^{1}$ \\ ${ }^{1}$ Department of Endocrinology, Metabolism and Pathobiochemistry, Eberhard-Karls-University Tübingen, Tübingen, Germany \\ ${ }^{2}$ Department of Pharmacology, Institute for Pharmaceutical Science, Eberhard-Karls-University, Tübingen, Germany
}

\begin{abstract}
Aims/hypothesis. Previous studies on diabetic patients have shown that hyperglycaemia increases glucose uptake in an apparently insulin-independent manner. However, the molecular mechanism has not been clarified.

Methods. We studied rats receiving continuous glucose infusion to address this question. In this animal model, rats accommodate systemic glucose oversupply and rapidly develop insulin resistance.

Results. Glucose infusion increased both plasma glucose and insulin concentrations to peak after one day. In spite of continuous glucose infusion normoglycaemia was reached after 5 days while insulin concentrations remained higher. Focusing our studies in day 2 (hyperglycaemia/hyperinsulinaemia) and day 5 (normoglycaemia/hyperinsulinaemia) we found, particularly in day 5 , that the early steps of the insulin signalling cascade in skeletal muscle of glucose-infused rats were not more activated when compared
\end{abstract}

to control animals as assessed by a comparable phosphorylation of the insulin receptor, IRS- 1 and PKB and by an unaltered IRS-1-associated Ptd(Ins) 3' kinase activity. Continuous glucose infusion induced GLUT4 protein expression and translocation to the plasma membrane while neither expression nor translocation of GLUT1 was affected. Translocation of PKC- $\beta$ I, $-\beta$ II (> threefold) and $-\alpha,-\theta$ (to a lesser extent) to the plasma membrane was significantly induced after 2 days but not after 5 days of glucose infusion when normoglycaemia was reached.

Conclusions/interpretation. Our data support the hypothesis that continuous glucose infusion induces translocation of GLUT4 while the early steps of the insulin signalling cascade were not increased. These effects could be mediated by activation of PKC. [Diabetologia (2002) 45: 356-368]

Keywords Hyperglycaemia, hyperinsulinaemia, insulin resistance, glucose transporter translocation, signal transduction, oversupply, protein kinase C.
Received: 6 August 2001 and in revised form: 18 October 2001

Corresponding author: Dr. E.D. Schleicher, Department of Endocrinology, Metabolism and Pathobiochemistry, Eberhard-Karls-University Tübingen, Otfried-Mueller-Str. 10, Tübingen, Germany, e-mail: enschlei@med.uni-tuebingen.de Abbreviations: DAG, 1,2-Diacylglycerol; PKB, protein kinase B; PKC, protein kinase C; GR, glucose-infused rats; C, control rats; $\alpha 1-D H P R$, dihydropyridine receptor subunit; GFAT, glutamine fructose-6-phosphate amidotransferase; IRS, insulin receptor substrate; PMSF, phenylmethylsulfonyl fluoride; RTPCR, reverse transcription polymerase chain reaction; Ptd(Ins) 3', kinase phosphatidylinositol-3' kinase; PM, plasma membrane; TT, transversal tubule
Impairment of the glucose transport in the insulinsensitive tissues contributes to the pathogenesis of Type II (non-insulin-dependent) diabetes mellitus [1, 2]. Skeletal muscle represents the most important tissue for the maintenance of a balanced postprandial glucose homeostasis; about $80 \%$ of insulin-stimulated glucose uptake is accounted for by muscle [3-5]. The influx of glucose into muscle is mediated by the glucose transporter proteins GLUT1 and the insulinsensitive GLUT4 [6-11]. Insulin induces the translocation of GLUT4 to the sarcolemma and to specialized deep invaginations of the plasma membrane of skeletal muscle known as transverse tubule (TT) membranes [12-14]. Insulin-independent GLUT4 
translocation in skeletal muscle can be induced by exercise or electro-stimulation [15]. Studies in diabetic patients revealed that hyperglycaemia leads to increased glucose uptake in skeletal muscle in a glucose concentration-dependent fashion [16]. The mechanism by which hyperglycaemia induces glucose uptake is poorly understood. Studies with cultured myotubes and isolated rat skeletal muscle showed that short-term hyperglycaemia is an insulin-independent inducer of GLUT4 translocation [17] and that PKC could be involved in this effect [17-24]. Moreover, studies with cultured cells [25] and animal models [17] show enhanced PKC activity is involved in mediating insulin resistance. The activation of PKC has been explained by the finding that the high glucoseinduced glucose metabolism leads to increased synthesis of DAG which in turn activates the corresponding PKC isoforms [26]. Short-term hyperglycaemia was reported to activate PKC isoforms in different cells [17, 25-28] and in isolated rat skeletal muscle $[17,18,20]$.

It has been shown that activated PKCs are involved in stimulating glucose transport [29-35] and translocation of glucose transporters by a mechanism which is distinct from that of insulin $[17,18,20,30,31$, $35,36]$. Other studies have focussed on the effect of $\mathrm{PKC}$ on the insulin signalling cascade showing that activation of PKC inhibits insulin-stimulated glucose transport in rat heart and skeletal muscle and rat adipocytes $[21,29,37]$. Taken together, in vitro studies indicate that acute increases in glucose induce activation of PKC which, on one hand, induces insulin-independent glucose uptake and, on the other hand, could mediate insulin resistance. To study if the proposed mechanisms are relevant in the intact organism, we used the glucose-infused rat model originally developed by Leahy et al. [38]. In this model, continuous systemic glucose oversupply induces insulin resistance in skeletal muscle and leads to significant hyperglycaemia [38-40]. Within days rats adapt to this state and reduce blood glucose to normal concentrations by processes which are not known $[39,40]$. The long-term glucose oversupply results in an increased glucose clearance with enhanced glucose uptake, lipogenesis and insulin action in adipose tissue while skeletal muscle showed a sustained insulin resistance with triglyceride accumulation [40]. It seems that this model mimics the pathobiochemical situation in human subjects with nutrient oversupply and subsequent insulin resistance associated with increased lipid accumulation in adipose tissue and skeletal muscle. Furthermore, the glucose oversupply leads to enhanced glucose sensitivity of the beta cell, ie. the beta cells of glucose-infused rats show enhanced insulin secretion at lower glucose concentrations [41]. This data could explain the hyperinsulinaemia seen in GR after 5 days, in spite of normoglycaemia (Table 2). Because these insulin concentrations might not explain the excessively increased glucose uptake into insulin resistant skeletal muscle, we studied the molecular mechanism of glucose-uptake under these conditions.

\section{Materials and methods}

Ketamine (Ketanest, Parke-Davis, Freiburg, Germany), Rompun (Bayer, Leverkusen, Germany) silicone rubber (Silastic, Dow Corning, Midland, Mich., USA), heparin (Liquemine, Roche, Grenzach, Switzerland), swivel (ZAK-Medizintechnik, Munich, Germany), syringe pump (Perfusor B. Braun, Melsungen, Germany), $50 \%$ glucose (Fresenius, Bad Homburg, Germany), nitrocellulose (Protran $0.45 \mu \mathrm{m}$, Schleicher and Schuell, Dassel, Germany), Dismembrator S (B. Braun, Melsungen, Germany). Buffer 1 contained $10 \mathrm{mmol} / \mathrm{l} \mathrm{NaHCO}$ $\mathrm{pH}=7.4,0.25 \mathrm{~mol} / \mathrm{l}$ sucrose, $5 \mathrm{mmol} / 1 \mathrm{NaN}_{3}$, freshly added protease inhibitor cocktail (Sigma, P8340) and $100 \mu \mathrm{mol} / \mathrm{l}$ PMSF, Bio-Rad-Kit (Biorad, Munich, Germany), NET-G $(150 \mathrm{mmol} / \mathrm{l} \mathrm{NaCl}, 5 \mathrm{mmol} / \mathrm{l}$ EDTA, $50 \mathrm{mmol} / \mathrm{l}$ TRIS-HCl $\mathrm{pH}$ 7.5, 0.05 Triton X-100, 0.25 g Gelatin (microbiology grade, Merck, Darmstadt, Germany). Antibodies against IR $\beta$, PY99, IRS-1, Ptd(Ins) 3' kinase-p85, PKB, PKC-isoforms, and GLUT1 and GLUT4 were purchased from Santa Cruz Technologies (Autogen Bioclear UK, Calne, Wiltshire, UK), pAkt1 (ser471) was purchased from Upstate Biotechnology (Lake Placid, N. Y., USA).

Animals. All surgical procedures performed in this study were approved by the local Animal Experimentation Ethics Committee and the principles of laboratory animal care (NIH publication no. 85-23, revised 1985) were followed. Female Wistar rats weighing about $300 \mathrm{~g}$ were purchased from Charles River, Sulzfeld, Germany and were kept at $22{ }^{\circ} \mathrm{C}$ with a $12 \mathrm{~h}$ lightdarkness cycle and a relative humidity of $55-60 \%$ during the whole experimental period. The rats were given free access to water and standard chow pellet diet (Altromin 1324, Altromin-Futterwerk, Lage, Germany).

Prolonged glucose infusion into conscious rats. Glucose infusion was performed as previously described [41]. Briefly, each rat was anaesthetized with an intraperitoneal injection of a mixture of Ketanest and Rompun at $45 \mathrm{mg} / \mathrm{kg}$ and $12 \mathrm{mg} / \mathrm{kg}$, respectively. Then 2-3 drops of atropine sulfate solution $(1 \mathrm{mg} / \mathrm{ml})$ was added for each millilitre of this mixture. Surgery was performed at semisterile conditions, using sterile instruments. A $1 \mathrm{~cm}$ long incision was made between sternum and mandibula, right external jugular vein was exposed by blunt dissection and was dissected free of the surrounding connective tissue. The jugular vein was cranial ligated and the vein was incised distal to the ligature. Catheters were constructed and were made of silicone rubber, polyethylene tube and silicone catheter fleece. The catheter were filled with 50 IU heparin in $0.9 \%$ saline and introduced into the vein so that its tip lay just before the right atrium. The catheter was then anchored by double ligature. The free end of the catheter was then routed dorsally subcutaneous to the back of the neck. A second incision was then made and the catheter was externalised and fixed using a Teflon anchoring device. The incision was then sutured. Externalised catheter was routed through a flexible spring tether to a swivel and connected by an oscillating arm to a Perfusor syringe pump. The rats were housed singly in a cylindrical Plexiglas metabolic cage and allowed to recover for $48 \mathrm{~h}$ after which glucose infusion $(2.77 \mathrm{~mol} / \mathrm{l}$ glucose $)$ was started at a rate of $2 \mathrm{ml} / \mathrm{h}(\mathrm{GR})$ versus $77 \mathrm{mmol} / \mathrm{l}$ saline in- 
fusion at $2 \mathrm{ml} / \mathrm{h}(\mathrm{C})$. A glucose and a saline-infusion were carried out at a time. Rats were allowed water and chow pellet ad libitum. Blood samples were taken from the tail vein and glucose and insulin concentrations were determined as previously described [41].

Isolation of hindlimb muscle. After 2 days or 5 days of continuous glucose or saline infusion, experiments were terminated by disconnecting the syringe pump. Rats were then immediately removed from the Plexiglas cage and killed. Hindlimb muscles were quickly excised, dissected free of connective tissue and fat and chopped in small pieces. This step was carried out on ice. Chopped muscles were immediately frozen in liquid nitrogen and subsequently stored at $-80^{\circ} \mathrm{C}$ until further preparation.

Plasma membrane preparation for the assessment of translocation of PKCs. Aliquots of excised muscles were weighed, ground in a liquid nitrogen-cooled porcelain mortar using a porcelain pistil. Muscles were subsequently placed in liquid nitrogen-cooled Dismembrator S (Braun, Melsungen, Germany) and powdered at setting $2000 \mathrm{rpm}$ for $1 \mathrm{~min}$. Powdered muscles were placed in ice-cold buffer 1 . Further homogenisation was carried out with a motor-driven Potter-Elvehjem Teflonglass tissue grinder (Braun, Melsungen, Germany) at setting $1500 \mathrm{rpm}$ and about 10 cycles. Crude muscle homogenate was then spun at $186000 \mathrm{~g}$ for $1 \mathrm{~h}$ using TLA 55 rotor (Beckman, Munich, Germany) and Optima Max centrifuge (Beckman). The supernatant was referred to as cytosolic fraction, whereas the pellet contained microsomal membrane fraction. The latter was resuspended in buffer 1 containing $1 \%$ Triton X-100, solubilized and centrifuged again at $10000 \mathrm{~g}$ in MLA 80 rotor (Beckman) for $10 \mathrm{~min}$. The supernatant was retained and referred to as microsomal membrane fraction. All steps were carried out at $4^{\circ} \mathrm{C}$.

Immunoprecipitation of IR and IRS-1. The immunoprecipitation procedure was used for the isolation of the insulin receptor and IRS 1. Briefly, $200 \mathrm{mg}$ of mixed hindlimb muscle were pulverised in a mortar and Dismembrator S and subsequently suspended in $1.5 \mathrm{ml}$ buffer containing $50 \mathrm{mmol} / \mathrm{l}$ HEPES $\mathrm{pH}$ $7.5,150 \mathrm{mmol} / 1 \mathrm{NaCl}, 1.5 \mathrm{mmol} / \mathrm{l} \mathrm{MgCl}_{2}, 1 \mathrm{mmol} / \mathrm{l}$ EGTA, $10 \%$ glycerol, $1 \%$ Triton $\mathrm{X}-100,100 \mathrm{mmol} / \mathrm{l} \mathrm{NaF}, 10 \mathrm{mmol} / \mathrm{l}$ $\mathrm{Na}_{4} \mathrm{P}_{2} \mathrm{O}_{7}$, and freshly added $1 \mathrm{mmol} / \mathrm{l} \mathrm{PMSF}, 20 \mu \mathrm{l} / 1.5 \mathrm{ml}$ buffer protease inhibitor cocktail and $400 \mu \mathrm{mol} / 1 \mathrm{Na}_{3} \mathrm{VO}_{4}$. Homogenate was then pottered as described above and spun at $10000 \mathrm{~g}$ for $10 \mathrm{~min}$ and the pellet was discarded. The last step was repeated. The protein concentration of the supernatant was measured, diluted with buffer to $10 \mu \mathrm{g}$ protein $/ \mu \mathrm{l}$ and $100 \mu \mathrm{l}$ of the latter dilution were added to $10 \mu \mathrm{l}$ Protein-ASepharose and $10 \mu$ l Sepharose (Pharmacia, Freiburg, Germany) and mixed. IR or IRS-1-antibodies $(5 \mu \mathrm{g})$ were added and gently rocked overnight at $4{ }^{\circ} \mathrm{C}$. Thereafter, beads were spun down at $500 \mathrm{rpm}$ for $1 \mathrm{~min}$. The pellet was washed three times and resuspended in $20 \mu \mathrm{l}$ washing buffer $(50 \mathrm{mmol} / \mathrm{l} \mathrm{HEPES}$ pH 7.5, $150 \mathrm{mmol} / 1 \mathrm{NaCl}, 0.1 \%$ Triton $\mathrm{X}-100,10 \%$ glycerol, $100 \mathrm{mmol} / \mathrm{l} \mathrm{NaF}$ and freshly added $\left.2 \mu \mathrm{mol} / \mathrm{l} \mathrm{Na}_{3} \mathrm{VO}_{4}\right)$. Eventually, Laemmli buffer was added and cups were heated at $98{ }^{\circ} \mathrm{C}$ for $10 \mathrm{~min}$. Supernatants were then quantitatively transferred to $7.5 \%$ SDS-PAGE (100 $\mu$ g protein), separated and detected as described below. Tyrosine phosphorylation was determined using the non site-specific anti-phosphotyrosine-antibody PY99.

Determination of IRS-1-associated Ptd(Ins) 3' kinase activity. IRS-1-associated Ptd(Ins) 3' kinase was determined after immunoprecipitation with IRS-1 antibody conjugated to beads
[18]. Briefly, collected immunoprecipitate were washed with phosphate-buffered saline $\mathrm{pH} 7.5$ containing $1 \% \mathrm{NP}-40$ and $100 \mu \mathrm{mol} / 1 \mathrm{Na}_{3} \mathrm{VO}_{4}$. Additional wash steps were performed and the enzyme activity was measured by incubation with Phosphatidylinositol (Avanti, Albaster, USA) and $\gamma$ ${ }^{32} \mathrm{P}[\mathrm{ATP}]$. Lipids were extracted using $\mathrm{CHCl}_{3}: \mathrm{CH}_{3} \mathrm{OH}$ [1:1] and radiolabelled product was separated by thin layer chromatography and detected by autoradiography.

Subcellular fractionation of rat skeletal muscle. Subcellular fractionation was carried out [42] with minor modifications. Mixed hindlimb muscles $(5 \mathrm{~g})$ were ground and homogenized as described above. The powdered muscle was placed in buffer 1 (5 g / $75 \mathrm{ml}$ buffer 1$)$ and pottered as described above. Subcellular fractionation was done for two experimental conditions at a time, ie. skeletal muscle of a control rat (C) and of a glucose-infused rat (GR). Muscle homogenate was spun at $1300 \mathrm{~g}$ for $10 \mathrm{~min}$ to remove large aggregates, nuclei and connective tissue. The postnuclear supernatant was saved and low spin pellet was resuspended, homogenized and pelleted again at $1300 \mathrm{~g}$ for $10 \mathrm{~min}$ (low spin pellet). Postnuclear supernatants were pooled and centrifuged at $9000 \mathrm{~g}$ for $10 \mathrm{~min}$. Supernatant was centrifuged at $190000 \mathrm{~g}$ for $1 \mathrm{~h}$ to yield the membrane-enriched pellet (microsomal pellet). Microsomal pellet was again resuspended, topped on a sucrose step gradient [42] and centrifuged at $150000 \mathrm{~g}$ for $7 \mathrm{~h}$ in swing-out rotor. Interphases from the gradient were then collected, diluted with sucrose free buffer 1 and repelleted at $444000 \mathrm{~g}$ for $1 \mathrm{~h}$. The low spin pellet is enriched in unbroken, partially broken cells as well as large sheets of the plasma membrane and T-tubules regions and contains about $40 \%$ of total GLUT4 and more than $50 \%$ of sarcoplasmatic reticulum [7]. Repeated washing of this pellet recovers no more than $20-30 \%$ of the surface membranes [7]. Therefore, low-spin pellet was resuspended in $\mathrm{LiBr}$ containing buffer $(50 \mathrm{mmol} / 1 \mathrm{TRIS}-\mathrm{HCl}, 0.5 \mathrm{~mol} / \mathrm{l} \mathrm{LiBr})$ and stirred at $4{ }^{\circ} \mathrm{C}$ for $4 \mathrm{~h}$. $\mathrm{LiBr}$ was added to break actin-myosin bond and liberates GLUT4-enriched internal membranes as previously described [42], [43]. The resulting homogenate was then first spun at $1200 \mathrm{~g}$ for $5 \mathrm{~min}$, the supernatant was centrifuged at $10000 \mathrm{~g}$ for $10 \mathrm{~min}$. The supernatant was centrifuged at $53000 \mathrm{~g}$ for $18 \mathrm{~min}$ to pellet a plasma membrane fraction enriched in T-tubules. The supernatant was centrifuged at $416000 \mathrm{~g}$ for $1 \mathrm{~h}$ to pellet intracellular membranes enriched in GLUT4. Pellets were resuspended in appropriate volume of buffer and protein concentration was measured.

Purity assessment of separated fractions. Identification and purity assessment of the separated fractions was previously described [42]. For characterization of the plasma membrane-enriched fractions we used $\alpha 1$ subunit of $\mathrm{Na}^{+}-\mathrm{K}^{+}$-ATPase as described $[44,45]$. For the characterization of fractions of enriched in transversal tubules the dihydropyridine receptor $\alpha 1$ subunit ( $\alpha 1$ DHPR) was used [45, 46].

Detection of GLUT4 and PKC isoforms by SDS-PAGE and immunoblotting. Protein concentrations were determined using the dye-based Bradford assay (Bio-Rad-Kit). Aliquots of proteins were applied to $7.5 \%$ SDS-PAGE [47]. Proteins were transferred to nitrocellulose by electroblotting. Nitrocellulose membranes were subsequently soaked with blocking agent (NET-G) for $1 \mathrm{~h}$ at room temperature. The first antibody dissolved in NET-G was then added and gently agitated for $2 \mathrm{~h}$ at room temperature or overnight at $4^{\circ} \mathrm{C}$. Membranes were subsequently washed in NET-G twice for 15 min each time and the horseradish peroxidase-conjugated second antibody was added and incubated at room temperature for $1 \mathrm{~h}$. Antibody detection was performed using a chemiluminescent de- 
Table 1. Primers used for the quantification of different mRNA.

\begin{tabular}{|c|c|c|}
\hline Primers & Primer sequence & $\begin{array}{l}\text { Product } \\
\text { length, } \\
\text { bp }\end{array}$ \\
\hline $\begin{array}{l}\text { IR } \\
\text { Forward } \\
\text { Reverse }\end{array}$ & $\begin{array}{l}\text { 5'-CTG GAT TAC GTG GAG GAC AA-3' } \\
\text { 5'-GTG AAG GTC TTG GCA GAA GC-3' }\end{array}$ & 381 \\
\hline $\begin{array}{l}\text { IRS-1 } \\
\text { Forward } \\
\text { Reverse }\end{array}$ & $\begin{array}{l}\text { 5'-CAA GGA GGT CTG GCA GGT TA-3' } \\
\text { 5'-GGT TGG AGC AAC TGG ATG AA-3', }\end{array}$ & 356 \\
\hline $\begin{array}{l}\text { Ptd(Ins) 3' } \\
\text { kinase, } \\
\text { Forward } \\
\text { Reverse }\end{array}$ & $\begin{array}{l}\text { 5'-TTC TTC CAG GCA AGT CAG GT-3' } \\
\text { 5'-GCC AGT GGA TGA CGG AGT TA-3' }\end{array}$ & 355 \\
\hline $\begin{array}{l}\text { PKC- } \alpha \\
\text { Forward } \\
\text { Reverse }\end{array}$ & $\begin{array}{l}\text { 5'-TCA ACT TCC TCA TGG TGC TG-3' } \\
\text { 5'-TGA CGT TGT CCA GCT TCA GA-3', }\end{array}$ & 393 \\
\hline $\begin{array}{l}\text { PKC- } \beta \text { I } \\
\text { Forward } \\
\text { Reverse }\end{array}$ & $\begin{array}{l}\text { 5'-CAG CAG GAA TGA CTT CAT GG-3' } \\
\text { 5'-CTT CAG GAT CTT CAC GGC AT-3' }\end{array}$ & 373 \\
\hline $\begin{array}{l}\text { PKC- } \delta \\
\text { Forward } \\
\text { Reverse }\end{array}$ & $\begin{array}{l}\text { 5'-GTG GTG TTG ATC GAC GAT GA-3' } \\
\text { 5'-CTT GAT GTG GCC ATC CTT GT-3' }\end{array}$ & 315 \\
\hline $\begin{array}{l}\text { PKC- } \zeta \\
\text { Forward } \\
\text { Reverse }\end{array}$ & $\begin{array}{l}\text { 5'-GAC GAA GTG CTC ATC ATC CA-3', } \\
\text { 5'-GGA AGG CAT GAC AGA ATC CA-3', }\end{array}$ & 309 \\
\hline $\begin{array}{l}\text { PKC- } \lambda \\
\text { Forward } \\
\text { Reverse }\end{array}$ & $\begin{array}{l}\text { 5'-CGG GAA GGT CTC CAT TTG AT-3' } \\
\text { 5'-GTT CCT TTG GGT CCT TGT TG-3' }\end{array}$ & 168 \\
\hline
\end{tabular}

tection reagent (Amersham-Pharmacia, Freiburg, Germany). Emitted light was collected on Hyperfilm ECL (Amersham, Freiburg, Germany). Films were developed using a Sterling Diagnostic Imaging apparatus (Du Pont de Nemours, Bad Homburg, Germany) and analysed by scanning densitometry using Sharp Scanner JX-330.

Measurement of glycogen and triglycerides in rat skeletal muscle. Glycogen assay from rat skeletal muscle was performed as previously described [48]. Briefly, $0.75 \mathrm{ml}$ of preheated (40 $\left.{ }^{\circ} \mathrm{C}\right)$ citrate buffer $(100 \mathrm{mmol} / \mathrm{l}$ sodium citrate, $\mathrm{pH} 5.0)$ were added to $100 \mathrm{mg}$ of pulverised mixed hindlimb muscle, mixed well and homogenized using Potter S at $1500 \mathrm{rpm}$ for $30 \mathrm{~s}$. Two sets of aliquots of $200 \mu \mathrm{l}$ were made from each sample. One of the sets was incubated with $0.5 \%$ amyloglucosidase in citrate buffer at $55^{\circ} \mathrm{C}$ for $150 \mathrm{~min}$ with periodical agitation (amyloglucosidase from aspergillus niger, A7420, Sigma, Munich, Germany). Samples were then centrifuged at 28000 rpm in TLA 55 rotor (Beckman, Munich, Germany) for 30 min. Supernatants were measured using YSI analyzer (YSI 2300 STAT Plus, Kraienbaum, Langenfeld, Germany). Observed and expected glucose readings of $0.1 \%$ glycogen standard (Type III from rat liver, Sigma) were processed for quantification. Triglycerides were analysed as described recently [40].

Preparation of total RNA from rat skeletal muscle and RT$P C R$. To isolate RNA, we used an optimized one step guanidinium isothiocyanate/phenol method (peqGOLD TriFast, peqLab Biotechnology, Erlangen, Germany). Isolation was done according to manufacturer's instructions. Reverse transcription was performed using a first strand cDNA synthesis Kit for RT-PCR with AMV (avian myeloblastis virus) as reverse transcriptase (Roche Diagnostics, Mannheim, Germany) and random primer $\mathrm{p}(\mathrm{dN})_{6}$. Reverse transcription was done in Perkin-Elmer-PCR-System 9700 (Überlingen, Baden-Württemberg, Germany). Primer design was made from a gene sequence of a discrete DNA segment, which was obtained from the Genome-GenBank. PCR was accomplished using the Light-Cycler-System (Roche Diagnostics, Mannheim, Germany). The SYBR Green I dye (Roche Diagnostics, Mannheim, Germany) was used for DNA detection. Beta globin was used as external standard for quantification, known amounts of beta globin were simultaneously run with samples and quantification was performed using the Light-Cycler-software version 3.0. Control rats were set at $100 \%$ and comparison was made to the corresponding treated rats. PCR product sizes were verified by gel electrophoresis on $2 \%$ agarose. Primers used are listed in Table 1.

Statistical analysis. All data are expressed as means \pm SEM. Data were analysed using the unpaired Student's $t$ test for the comparison of mean values. Data are expressed in per cent of control animals. A $p$ value of less than 0.05 was considered to be statistically significant.

\section{Results}

Metabolic effects of continuous glucose infusion. Continuous glucose infusion into rats for 7 days induced transient hyperglycaemia and persistent hyperinsulinaemia (Table 2). Hyperglycaemia peaked after $24 \mathrm{~h}$ of glucose infusion. Despite further continuous glucose infusion, plasma glucose reached normal values in infused rats compared to controls in the fifth day (day 5: $7.3 \pm 0.4 \mathrm{GR}$ vs $6.9 \pm 0.06 \mathrm{mmol} / \mathrm{l}$ C) and remained normal after day 7 . We observed about a 20 -fold increase in serum insulin concentration after one day of glucose infusion which declined thereafter but remained elevated throughout the glucose infusion period (5d: $219 \pm 10 \mathrm{GR}$ vs $38 \pm 1 \mu \mathrm{U} / \mathrm{ml} \mathrm{C}$ ). Saline infusion affected neither plasma glucose nor insulin concentration in control rats (Table 2). Glucosuria was present after 2 days but was absent after 5 days (Table 3 ). As expected, glucose-infused rats showed faster weight gain and lower food consumption (Table 3 ). The parallel reduction of both glucose and insulin concentrations indicates the action of an insulin-independent glucose uptake system. Because the metabolism of the rats changed from the hyperglycaemic/hyperinsulinaemic state in day 2 to the normoglycaemic/hyperinsulinaemic state in day 5 , we focused our studies on these two time points. To assess whether increased glucose uptake into skeletal muscle and subsequent enhanced glucose utilization had occurred, glycogen and triglycerides content were measured. As shown in Table 3 glycogen content increased more than 10 -fold after 2 days of glucose infusion and was less increased after 5 days (3.5fold). The muscle triglyceride content was increased $(p<0.05)$ after 2 days and remained higher after 
Table 2. Effect of glucose infusion on plasma glucose and insulin concentrations.

\begin{tabular}{|c|c|c|c|c|c|c|}
\hline Parameter & $\begin{array}{l}\text { Controls (saline) vs } \\
\text { GR (glucose) }\end{array}$ & Day 0 & Day 1 & Day 2 & Day 5 & Day 7 \\
\hline Glucose & $\begin{array}{l}\mathrm{C} \\
\text { GR }\end{array}$ & $\begin{array}{l}135 \pm 5 \\
145 \pm 5\end{array}$ & $\begin{array}{l}130 \pm 2 \\
475 \pm 29^{*}\end{array}$ & $\begin{array}{l}134 \pm 2 \\
338 \pm 3^{*}\end{array}$ & $\begin{array}{l}125 \pm 1 \\
132 \pm 7\end{array}$ & $\begin{array}{l}123 \pm 3 \\
126 \pm 8\end{array}$ \\
\hline IRI & $\begin{array}{l}\mathrm{C} \\
\text { GR }\end{array}$ & $\begin{array}{l}39 \pm 1 \\
42 \pm 2\end{array}$ & $\begin{array}{c}41 \pm 1 \\
903 \pm 43^{*}\end{array}$ & $\begin{aligned} 44 & \pm 2 \\
595 & \pm 17 *\end{aligned}$ & $\begin{array}{c}38 \pm 1 \\
219 \pm 10^{*}\end{array}$ & $\begin{array}{c}49 \pm 4 \\
155 \pm 11 *\end{array}$ \\
\hline
\end{tabular}

C, control rats, GR, rats treated with glucose infusion, IRI, immunoreactive insulin

Data representing results of five independent experiments are expressed as means \pm SEM and significance $p<0.001$ is indicated by*

Table. 3. Effect of continuous glucose infusion on metabolic parameters

\begin{tabular}{lcccc}
\hline Infusion period & Day 2 C & GR & Day 5 C & GR \\
Glucose infused (mmol/d) & 0 & 133 & 0 & 133 \\
\hline Urine glucose & Negative & Positive & Negative & Negative \\
Food consumption (g/d) & $10 \pm 0.3$ & $7.8 \pm 0.2^{*}$ & $12 \pm 0.3$ & $7 \pm 0.3^{*}$ \\
Gained weight (g/d) & $1.8 \pm 0.1$ & $3 \pm 0^{*}$ & $1.8 \pm 0.1$ & $3.4 \pm 0.2^{*}$ \\
Glycogen content (mg/g muscle) & $3.3 \pm 0.7$ & $49 \pm 5.6^{* *}$ & $4.5 \pm 0.9$ & $15.9 \pm 2^{*}$ \\
Triglyceride content (pmol/kg muscle) & $244.9 \pm 36$ & $417 \pm 42^{*}$ & $166.3 \pm 29$ & $426 \pm 74^{*}$ \\
\hline
\end{tabular}

$\mathrm{C}$, control rats, GR, rats treated with glucose infusion. Data $* p<0.05$

represent means \pm SEM $\quad * * p<0.001$

Table 4. Effect of glucose infusion on the insulin signalling cascade in rat skeletal muscle. IRS-1-associated Ptd(Ins) 3' kinase activity was determined after immunoprecipitation with IRS-1 antibody conjugated to beads. Western blots, as shown

\begin{tabular}{lcccc}
\hline & Protein Day 2 & Day 5 & mRNA Day 2 & Day 5 \\
\hline IR- $\beta$-subunit & $113 \pm 3$ & $83 \pm 3^{*}$ & $151 \pm 27$ & $64 \pm 9^{*}$ \\
IR-p-tyrosine & $118 \pm 11$ & $78 \pm 1^{*}$ & - & - \\
IRS-1 & $120 \pm 27$ & $94 \pm 9$ & $126 \pm 20$ & $142 \pm 16$ \\
IRS-1-p-tyrosine & $109 \pm 18$ & $102 \pm 5$ & - & - \\
Ptd(Ins) 3' kinase-(p85) & $84 \pm 8$ & $93 \pm 8$ & $74 \pm 25$ & $100 \pm 17$ \\
Ptd(Ins) 3' kinase activity & $97 \pm 18$ & $108 \pm 10$ & n.d. & - \\
PKB & $98 \pm 4$ & $83 \pm 6$ & - & n.d. \\
P-serine & $85 \pm 7$ & & - \\
\hline
\end{tabular}

Data represent means \pm SEM

$* p<0.05$

5 days of glucose infusion. These data, together with the weight gain $(p<0.05)$ clearly indicate that the excess glucose was utilized.

Insulin signalling cascade. Earlier studies with this model have shown that continuous glucose infusion induces both increased glucose metabolism and insulin resistance in rat skeletal muscle [39, 40, 49]. To see if increased glucose-uptake in glucose-infused rats is mediated by an enhanced insulin action, we studied the amount and activity of the known early steps insulin signalling proteins. Extracts from rat skeletal muscle were analysed by Western blotting. A typical experiment is shown in Figure 1 and all data measured are summarized in Table 4 . We found that protein and mRNA expression and phosphorylation of proteins of the insulin signalling cascade were not increased after 2 days and particularly after

in (Fig. 1), from three independent experiments were scanned. Quantification of mRNA was measured using the Light Cycler system in three independent experiments. Values are expressed as percent of controls, which were set at $100 \%$.

\section{(1)}




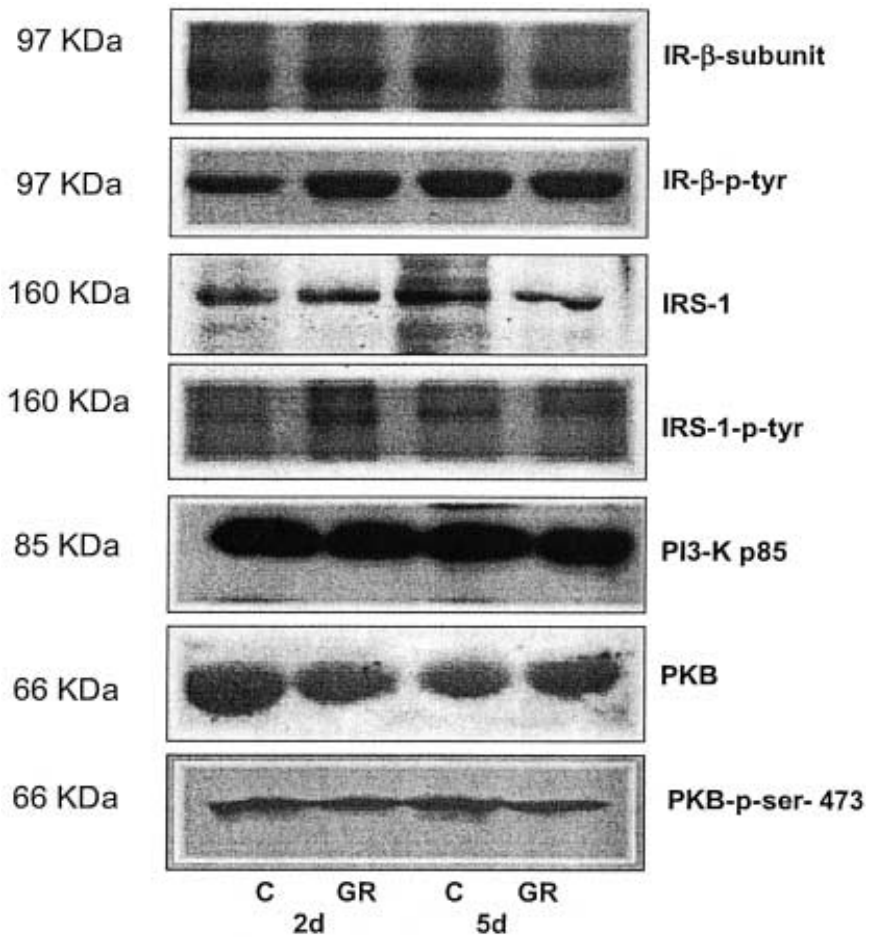

Fig. 1. Effect of glucose infusion on the insulin signalling cascade in rat skeletal muscle after day 2 and day 5 of glucose infusion. Glucose infusion $(5.6 \mathrm{mmol} / \mathrm{h})(\mathrm{GR})$ and continuous infusion of $154 \mu \mathrm{mol} / \mathrm{h} \mathrm{NaCl}$ into control rats (C) was done as described in the Methods. Representative Western Blots from three independent experiments are shown

\section{GLUT4}

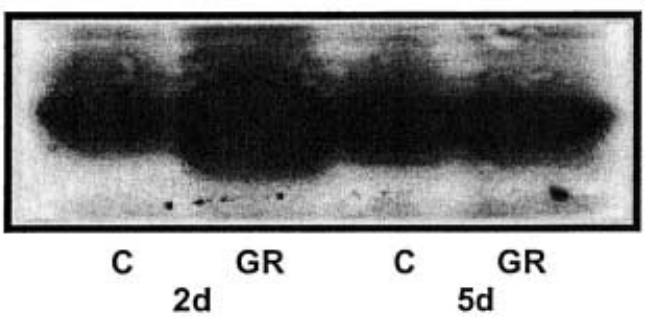

Fig. 2. Protein expression of GLUT4 in rat skeletal muscle after 2 and 5 days of glucose infusion. Homogenates were prepared from glucose-infused (GR) and control (C) rats and Western blotting was performed. Representative Western blots are shown from a set of three independent experiments

indicating no increase in insulin receptor activation in glucose-infused rats (Table 4). Furthermore, the expression of the downstream signalling proteins IRS1, Ptd(Ins) 3' kinase-p85, PKB and the tyrosine phosphorylation of IRS-1 as well as serine-473 phosphorylation of PKB were not affected. Because activation of Ptd(Ins) 3' kinase has been shown to be an essential step in insulin-dependent stimulation of glucose transport, IRS-1 associated Ptd(Ins) 3' kinase from muscle extracts was precipitated using IRS-1 antibody and analysed for enzymatic activity using thin layer chromatography for the separation of the radioactive Ptd(Ins) 3' kinase product as previously described [18]. No significant increase in IRS-1-associated $\operatorname{Ptd}($ Ins) 3' kinase activity was found in glucoseinfused rats (Table 4). Similarly, expressions of the mRNA of the investigated proteins, except IR, were not significantly changed (Table 4). It appears that after 5 days of glucose infusion a down regulation of the IR is initiated. Together, these data indicate that neither expression of the components of the insulin signalling cascade nor their activity is significantly increased by continuous glucose infusion after 2 or 5 days. These data explain the earlier finding that glucose oversupply induces insulin resistance in skeletal muscle $[39,40,49]$.

Expression of GLUT1 and GLUT4 protein. Because prolonged glucose infusion stimulated glucose utilization in skeletal muscle, as assessed by an increase in glycogen and triglyceride content, without employing the insulin signalling cascade, we examined any insulin-independent effects on the glucose transporters GLUT1 and 4. First, we studied if continuous glucose infusion had altered the expression of GLUT1 and GLUT4. Skeletal muscle homogenates were prepared from GR and controls, and equal amounts of protein $(100 \mu \mathrm{g})$ were loaded on the gel. Western blotting revealed an increase in protein expression of GLUT4 after 2 days of glucose infusion $(p<0.01)$ which remained slightly increased after 5 days of glucose infusion $(p<0.05)$ (day 2: $158 \pm 4 * * \%$ of control; day $5: 111 \pm 3 * \%$ of control) (Fig. 2). In contrast, no changes in GLUT1 protein expression were found (data not shown).

The translocation of GLUT1 and GLUT4. Previous studies have shown that an appreciable amount of GLUT1 and GLUT4 protein is located in intracellular vesicles. However, only the glucose transporters which are inserted into the plasma membrane are functionally active [9]. Therefore, we determined the presence of the glucose transporter proteins GLUT1 and GLUT4 in the plasma membrane of rat skeletal muscle to assess whether in vivo glucose infusion induced the translocation of the transporters. Because insulin induces the translocation of GLUT4 particularly to the transversal tubules (TT) of the plasma membrane $[42,50,51]$ this membrane compartment was also studied. The identity and purity of the TT fraction was assessed by the presence of $\alpha_{1}$ dihydropyridine receptor which is exclusively located in the TT membranes [52]. We observed an increase of GLUT4 in all plasma membrane fractions studied after 2 days while the effect was much less pronounced after 5 days of glucose infusion (Fig. 3A). Characterization of the plasma membrane fractions by blotting against the $\alpha_{1}$-subunit of the $\mathrm{Na}^{+}-\mathrm{K}^{+}$-ATPase, a marker for plasma membranes, showed that this 

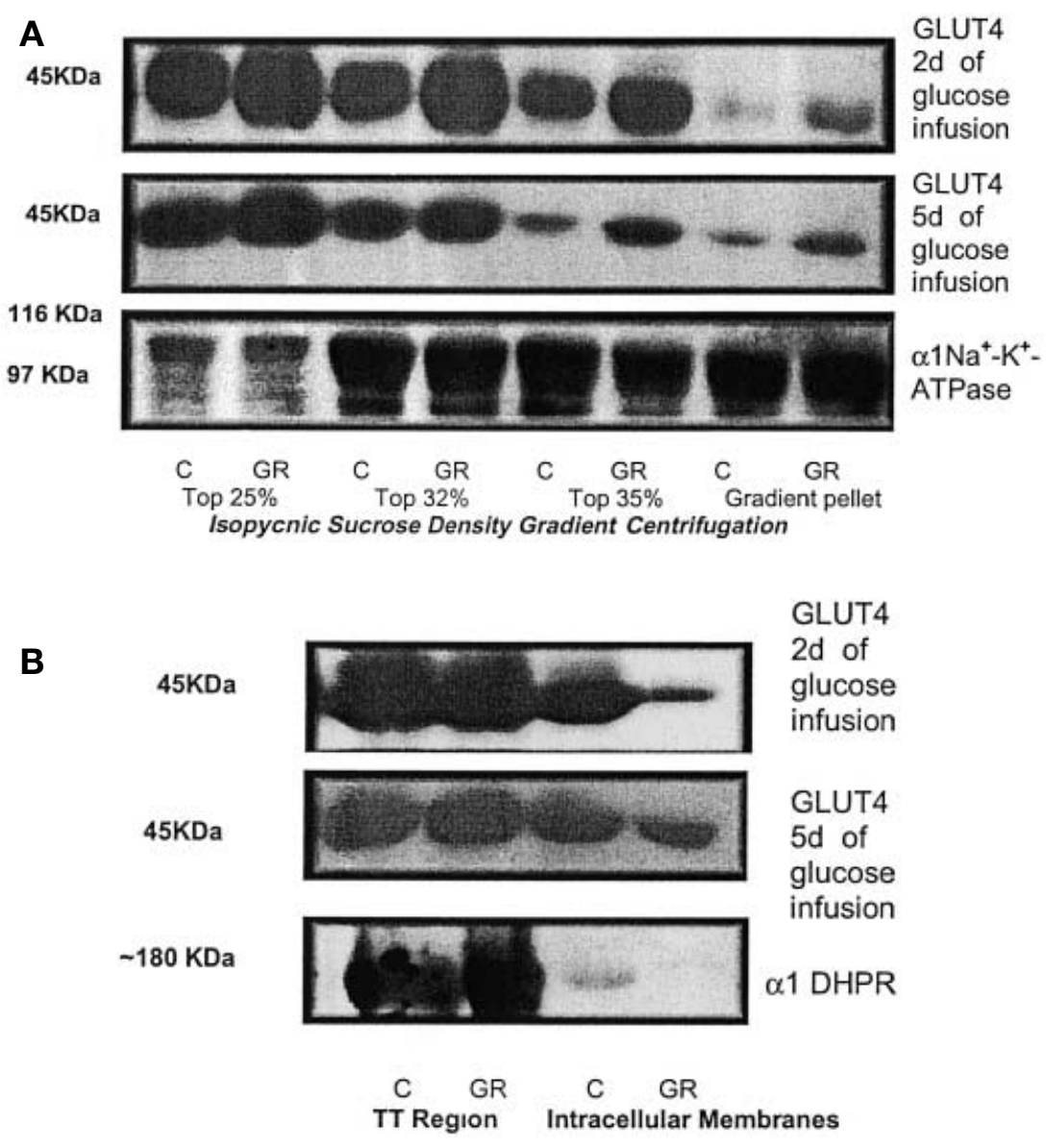

Fig.3 (A, B). Effect of glucose infusion on the distribution of GLUT4 in cellular compartments of rat skeletal muscle after day 2 and day 5. Plasma membrane fractions obtained by step gradient centrifugation are shown in $(\mathbf{A})$. Intracellular fractions and transverse tubule (TT) membranes are shown in (B). $\alpha 1$-Subunits of $\mathrm{Na}^{+} / \mathrm{K}^{+}$-ATPase and dihydropyridine receptor ( $\alpha 1$ DHPR) were determined to assess the purity of the obtained fractions. Representative Western Blots of three independent experiments are shown

marker was clearly enriched in the $32 \%$ and $35 \%$ sucrose gradient and in the gradient pellet (Fig. 3A), indicating that these fractions originate from the plasma membrane. The $25 \%$ fraction mainly containing intracellular membranes also showed a small increase in GLUT4 after glucose infusion. This increase could be caused by the contamination with plasma membrane fraction because this fraction contains small but noticeable amounts of the $\alpha_{1}$-subunit of the $\mathrm{Na}^{+}-$ $\mathrm{K}^{+}$-ATPase (Fig. 3A). Furthermore, we investigated whether increased translocation affected the intracellular pools. GLUT4 was almost completely depleted in the intracellular membranes after 2 days and to a lesser extent after 5 days of glucose infusion (Fig. 3B). Although the absolute content of the GLUT4 protein varied, a clearly increased GLUT4 translocation was observed in three different mem- brane preparations. These data indicate that in the presence of insulin hyperglycaemia caused a persisting induction of glucose uptake through GLUT4 translocation. No change in GLUT4 content was observed in the transversal tubule membrane fraction after 2 days or 5 days of glucose infusion (Fig. 3B).

To evaluate the specificity of this effect, we also studied GLUT1 in the different cell compartments using the same fractions as described above. In contrast to GLUT4, GLUT1 is primarily located in intracellular membranes ( $25 \%$ fractions) and to a lesser extent in the plasma membranes of the $32 \%$ and $35 \%$ fraction. No change of GLUT1 content was observed in any of the membrane fractions after day 2 or after day 5 of glucose infusion (data not shown), indicating that the persisting hyperglycaemia-induced glucose uptake is not mediated by GLUT1.

The translocation of PKC isoforms. As outlined by several earlier studies high glucose could activate PKC. Activated PKC isoforms inhibit insulin signalling and stimulate GLUT4 translocation. Therefore, the cellular localization of the PKC isoforms PKC- $\alpha$, $-\beta \mathrm{I},-\beta \mathrm{II},-\theta,-\lambda,-\delta$ and $-\xi$ was studied to assess possible activation by the experimental metabolic conditions. Because PKC- $\varepsilon$ is known to be translocated in skeletal muscle in this animal model [40], this isoform was not investigated here. Equal amounts of proteins 


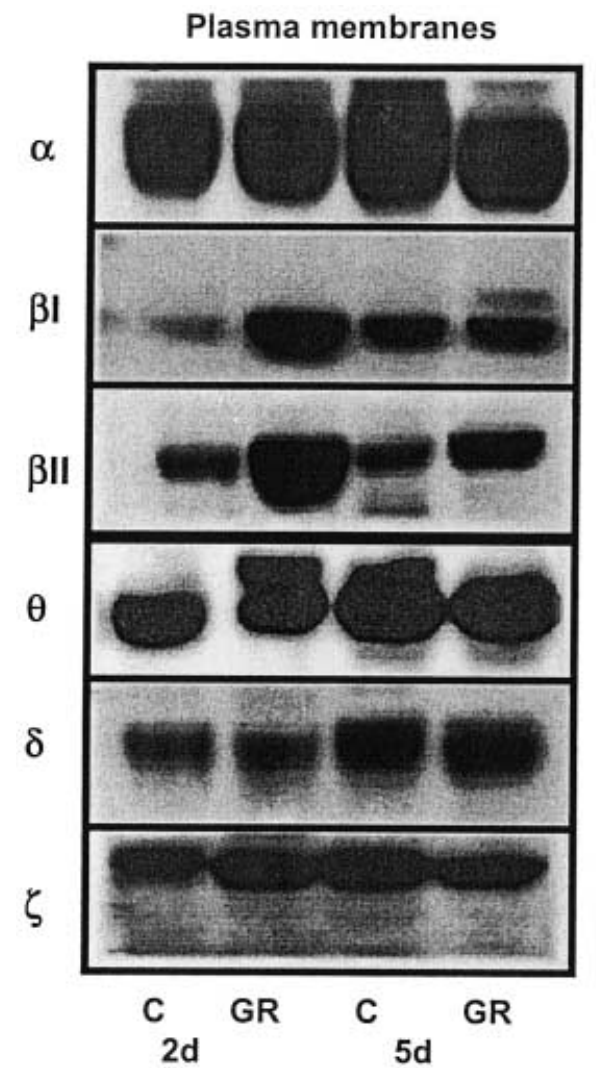

Fig. 4. Effect of glucose infusion on the translocation of PKC isoforms in rat skeletal muscle. Hindlimb skeletal muscles were prepared from glucose-infused (GR) or saline-infused (C) rats and the plasma membrane and cytosolic fraction was obtained as described in Methods. Representative Western blots are shown from a set of three independent experiments

from the plasma membrane and the cytosol fractions were separated by gel electrophoresis and were immunoblotted. The specificity of the antisera was verified by competition with the peptide used for immunisation (data not shown). The cPKCs $-\alpha,-\beta \mathrm{I}$ and $-\beta$ II ( $\gamma$ is not expressed in skeletal muscle) were enriched in the PM after 2 days of glucose infusion and the corresponding cytosolic fractions were simultaneously depleted (Fig.4). Quantification of the data (Table 5) indicated that the glucose infusion caused more than 3 -fold enrichment of PKC- $\beta \mathrm{I}$ and $-\beta \mathrm{II}$ in the PM, ie. the highest increase of all PKC isoforms studied, while the effect on PKC- $\alpha$ was much smaller. The cytosolic fraction was substantially reduced in PKC- $\alpha,-\beta I$ and $-\beta$ II after 2 days (Table 5). After 5 days the changes were no longer detectable. Specific bands of the novel PKC $-\delta$ and $-\theta$ were immunodetectable. PKC- $\theta$ increased $(p<0.05)$ in the PM after 2 days but not after 5 days of glucose infusion (Table 5). The slight increase of PKC- $\delta$ on day 2 was not statistically significant. We found no increased translocation of PKC- $\zeta$ in skeletal muscle samples after 2 days or 5 days. When we used PKC- $\lambda$ antibody,
Cytosolic fractions

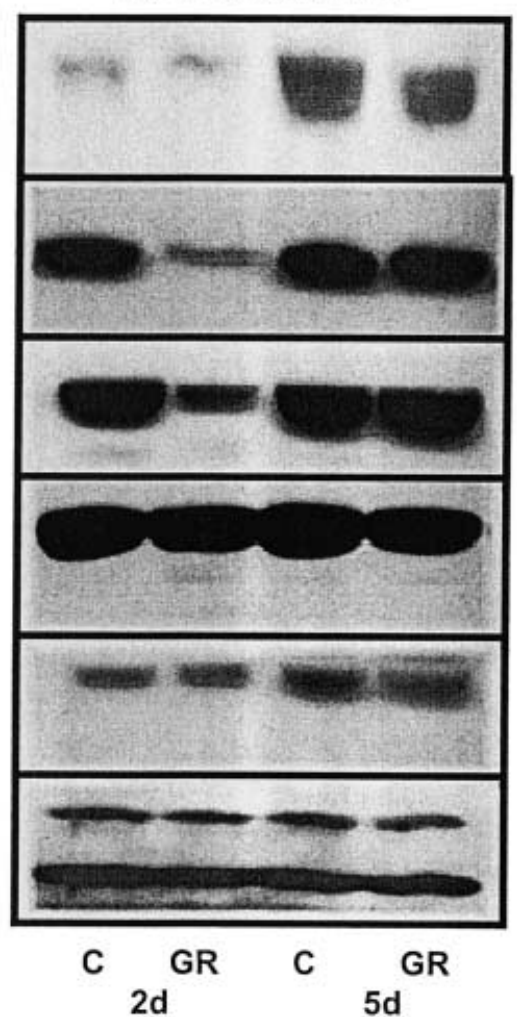

we obtained no specific immunoreactivity. To exclude a possible effect of glucose infusion on PKC expression, we investigated the amount of total PKC isoforms present in homogenates by Western blotting and PKC isoform mRNA by real time RT-PCR. No specific change in the protein or mRNA expression of any of the isoforms studied was found in day 2 or day 5 (Table 6). The results show that continuous glucose infusion leads to translocation of PKC- $\alpha,-\theta$ and particularly $-\beta \mathrm{I}$ and $-\beta \mathrm{II}$ and that the translocation was only evident when hyperglycaemia was present.

\section{Discussion}

Studies in diabetic and normal subjects have indicated that hyperglycaemia induces an increase in glucose uptake which has been attributed to mass action of glucose [16]. Our previous in vitro studies with cultured myotubes and isolated skeletal muscle show that short-term hyperglycaemia induced an insulinindependent glucose uptake and a parallel translocation of GLUT4 to the cell surface, indicating that high glucose concentrations could activate their own uptake system [17]. However, numerous hormones, such as glucagon, catecholamines, thyroid hormone and other still ill-defined mediators, mediating the cross-talk between fat and muscle, influence glucose uptake and metabolism rendering the in vivo situation much more complex. To address the molecular mechanisms of hyperglycaemia-induced glucose up- 
Table 5. Quantification of the effect of glucose infusion on PKC isoforms translocation. Western blots as shown in (Fig. 4) from three independent experiments were scanned. Values are expressed as $\%$ of control values, which were set at $100 \%$.

\begin{tabular}{|c|c|c|c|c|}
\hline \multirow[t]{2}{*}{$\mathrm{PKC}$ isoform } & \multicolumn{2}{|c|}{ Plasma membrane } & \multicolumn{2}{|c|}{ Cytosol fraction } \\
\hline & day 2 & day 5 & day 2 & day 5 \\
\hline$\alpha$ & $121 \pm 8^{*}$ & $94 \pm 15$ & $47 \pm 8^{*}$ & $76 \pm 14$ \\
\hline$\beta \mathbf{I}$ & $329 \pm 67^{*}$ & $93 \pm 3$ & $45 \pm 14^{*}$ & $95 \pm 3$ \\
\hline$\beta \mathrm{II}$ & $417 \pm 119^{*}$ & $114 \pm 13$ & $54 \pm 23^{*}$ & $114 \pm 11$ \\
\hline$\delta$ & $153 \pm 28$ & $102 \pm 3$ & $92 \pm 5$ & $115 \pm 1$ \\
\hline$\theta$ & $144 \pm 12^{*}$ & $106 \pm 10$ & $71 \pm 15$ & $97 \pm 5$ \\
\hline$\zeta$ & $129 \pm 18$ & $78 \pm 10$ & $70 \pm 41$ & $60 \pm 24$ \\
\hline
\end{tabular}

Data represents means $\pm \mathrm{SEM}$

$* p<0.05$

Table 6. Effect of glucose infusion on PKC isoforms mRNA expression. mRNA expression of PKC isoforms were determined by RT-PCR. Results from three independent experiments were used. Values are expressed as \% of controls, which were set at $100 \%$.

\begin{tabular}{lcc}
\hline PKC isoform & \multicolumn{2}{c}{ mRNA expression } \\
\cline { 2 - 3 } & \multicolumn{1}{c}{ day 2} & day 5 \\
\hline$\alpha$ & $77 \pm 23$ & $114 \pm 24$ \\
$\beta$ & $135 \pm 24$ & $93 \pm 38$ \\
$\delta$ & $92 \pm 22$ & $87 \pm 72$ \\
$\theta$ & n.d. & n.d. \\
$\zeta$ & $117 \pm 23$ & $110 \pm 58$ \\
$\lambda$ & $78 \pm 12$ & $95 \pm 67$ \\
\hline
\end{tabular}

Data represent means \pm SEM

$* p<0.05$

n.d. $=$ not determined

take in vivo, we used the glucose-infused rat model originally developed by Leahy et al. [38]. In this model, rats adapt to and minimize the degree of hyperglycaemia despite continuously ongoing systemic glucose oversupply $[39,53]$. This adaptation cannot be explained by compensatory renal glucose clearance $[39,53]$. As previously shown, not all glucose is taken up by muscle and fat tissue but also by the liver and other tissues indicating a role of these organs in glucose homeostasis [53]. Because insulin resistance rapidly develops in the skeletal muscle of the glucose-infused rats $[39,53]$ it seems that glucose in itself could play a major role in the adaptation process, ie. accommodation of systemic glucose oversupply and return to normoglycaemia.

Using this animal model, we confirmed previous reports of rapid adaptation of the rats to the glucose infusion resulting in normoglycaemia and persistent hyperinsulinaemia after 5 days. Reduced food intake cannot account for the normalization of the plasma glucose values because the amount of infused glucose $(24 \mathrm{~g} / \mathrm{d})$ clearly exceeds the amount of reduced food uptake ( $5 \mathrm{~g}$ of chew pellet) by far. Investigating the underlying molecular mechanism, we found that the normalization of blood glucose concentration was mediated at least partially by an increased transloca- tion of GLUT4 to the plasma membrane of skeletal muscle because an increase in GLUT4 protein in all plasma membrane fractions studied was detected. GLUT1 appeared not to be involved in the increased glucose uptake because no changes in either translocation or protein expression were detected. Because insulin induces the translocation of GLUT4 in skeletal muscle, we studied whether the insulin signalling cascade was more activated in GR than in ad libitum fed control animals. Activation of insulin signalling could be assessed by determination of the tyrosine phosphorylation of the insulin receptor and the well characterized proximal substrate molecule IRS-1 [54]. Phosphorylation of IRS-1 creates binding sites for the regulatory p85 subunit of Ptd(Ins) 3' kinase, a key mediator in insulin signalling. IRS-associated Ptd(Ins) 3' kinase produces phosphatidylinositol3,4,5-phosphate which activates phosphatidylinositol-3,4,5-phosphate-dependent-kinase-1, in turn activating $\mathrm{PKB}$ by phosphorylation at ser 473 [55]. Because activated PKB is thought to transmit the insulin signal to glucose uptake and to glycogen synthesis, activation of PKB was also studied in GR [55]. Recently, insulin-dependent activation of $\mathrm{PKC}-\zeta$ has been implicated in insulin signalling [32]. Although many components of the signalling pathway of insulin-induced translocation of GLUT4 have been characterized, the complete sequence of events is not known [55]. Because the expression of the insulin receptor [56] and other insulin signalling proteins could vary, we estimated both the mRNA and the protein expression of the signalling proteins [54].

The insulin signalling cascade particularly in day 5 , as assessed by the determination of phosphorylation of the insulin receptor, IRS-1 and PKB, was not further activated when compared to control rats suggesting that the increased GLUT4 translocation is not mediated by the insulin-dependent steps studied. In addition, the PKC isoform $\zeta$ previously shown to be activated by insulin was not changed providing further support for the inhibition of the early steps of insulin signalling cascade [32]. Noteworthy, in contrast to an insulin-dependent GLUT4 translocation [12, $13,14]$, we observed no translocation of GLUT4 to 
the transverse tubules in GR providing more evidence for a possibly different mechanism of insulininduced and hyperglycaemia-induced GLUT4 activation.

We previously reported that high glucose concentrations interact in a dual way with the insulin signalling cascade; hyperglycaemia induced translocation of GLUT4 in three different muscle-derived model systems [17] and hyperglycaemia induced insulin resistance in rat-1 fibroblasts [19]. In agreement with this, several studies reported an hyperglycaemia-induced increased glucose uptake $[18,20]$. In this study, we found such an effect on GLUT4 translocation in whole, insulin-resistant animals. It is probable that the increase in GLUT4 expression and translocation is responsible for lowering of blood glucose because the increased glycogen and lipid content in the skeletal muscle of GR provides evidence for the functionality of the translocated GLUT4.

Because the increased GLUT4 translocation does not seem to be mediated by an enhanced activation of the early steps of insulin signalling, we studied the possible mechanism of this effect. Several studies suggested a role of PKC in hyperglycaemia-induced glucose uptake $[17,18,20]$ and in insulin resistant states $[19,25,57-59]$. PKC overexpression or long-term exposure to TPA down regulates IRS-1 expression and leads to insulin resistance [60]. We have previously reported that the PKC isoform $\beta$ is important for the short-term high glucose effect in muscle [17]. Hyperglycaemia has been shown to induce translocation of PKC- $\beta$ I and $-\beta$ II [20]. However, the effect on PKC$\beta$ I failed to reach statistical significance in the latter study. PKC isoform $\beta$ was reported to be activated under hyperglycaemic conditions in breast cancer cells [61], in $\mathrm{C}_{2} \mathrm{C}_{12}$ myotubes and rat skeletal muscle $[17,18]$, in rat heart muscle [30] and in human skeletal muscle cells [62]. Overexpression of PKC- $\beta$ I and PKC- $\beta$ II but not PKC- $\delta,-\varepsilon,-\theta$ or $-\zeta$ inhibited the tyrosine kinase activity of the insulin-stimulated insulin receptor [57]. Our finding of an hyperglycaemia-induced PKC- $\beta \mathrm{I} / \beta \mathrm{II}$ translocation in skeletal muscle of glucose-infused rats is well in line with these studies. Recently, the effect of PKC activation on insulin signalling in ex vivo rat soleus muscle was studied [63]. Muscle preincubated for $1 \mathrm{~h}$ with $1 \mu \mathrm{mol} / 1$ phorbol ester resulted in translocation of PKC $-\alpha,-\beta \mathrm{I},-\beta \mathrm{II},-\varepsilon$ and $-\theta$ similar to our present results obtained in intact glucose-infused rats. The phorbol ester treated muscles showed an impaired ability of insulin to stimulate glucose incorporation into glycogen while insulinstimulated glucose transport and oxidation and glucose incorporation into lipid was not affected. Of note, we found a relative decrease in glycogen content after 5 days while the lipid content was not changed (Table 3). The pharmacological PKC activation decreased insulin-stimulated phosphorylation of the insulin receptor, PKB and glycogen synthase kinase
3 while $\operatorname{Ptd}(\mathrm{Ins}) 3$ ' kinase activity was less reduced. These results indicate that phorbol-ester-stimulated activation of PKC leads to an impairment of several but not all events in the insulin signalling cascade. The striking similarity of these results to our data indicate that the observed PKC activation could actually cause the effects in our in vivo model of glucose oversupply.

Using the same animal model, investigators [40] showed that PKC- $\varepsilon$, but not PKC- $\alpha,-\delta$ or $-\theta$ was translocated in the day 1 and day 4 of continuous glucose infusion; PKC- $\beta$ was not studied. These and our data indicate that the PKC isoforms $\alpha, \beta$ and possibly $\theta$ (this study) and $\varepsilon$ [40] could be most relevant to explaining the effects observed in this animal model. Including the results obtained by in vitro studies, it could well be that these PKC isoforms activated by hyperglycaemia regulate signalling in a dual way: inhibition of early steps of insulin signalling as well as opening of an hitherto unknown signalling pathway which induces GLUT4 translocation. Because high insulin concentrations are present at both time points studied, we cannot rule out an insulin-mediated increase in GLUT4 translocation. An IRS-1- and PKB-independent pathway for insulin-dependent GLUT4 translocation has been characterized [64]. Furthermore, other proteins of the IRS family could be involved because eg. IRS-2 deficient mice also have abnormalities in peripheral insulin action [65]. In addition, there could be other unknown insulin-dependent or insulin-independent signalling cascades which induce the increase in glucose uptake. Although plasma insulin concentrations remain high after the 5 days of glucose infusion, they are not believed to be high enough to activate IGF-1 receptormediated glucose uptake.

A study of the molecular mechanism of PKC activation and induction of insulin resistance in this animal model found an increased accumulation of longchain acyl-CoA which could be linked to an activation of PKC and insulin resistance [40]. Furthermore, they found an increased triglyceride content in skeletal muscle similar to our results [49]. Noteworthy, higher muscle triglycerides concentrations have been detected in insulin-resistant non-diabetic human subjects $[66,67]$. Studies provide evidence that the hexosamine biosynthetic pathway is involved in the development of insulin resistance [68]. Hyperglycaemia increases GFAT activity and GFAT activity is increased in hyperglycaemic obese mice and in hyperglycaemic subjects with Type II diabetes [69-71]. Transient overexpression of GFAT leads to insulin resistance indicating that this pathway could also be activated in skeletal muscle of glucose infused rats [72]. Of note, recent results showed that activation of this pathway leads to activation of PKC [21] and induces translocation of the PKC isoforms $\alpha, \varepsilon$ and particularly $\beta$, but not $\zeta$ [73] supporting the possibility 
of an involvement of the hexosamine pathway in the pathogenesis of insulin resistance.

In summary, this study suggests that in skeletal muscle of long-term glucose-infused rats early steps of insulin signalling are impaired possibly leading to reduced glycogen synthesis while triglyceride accumulation is not affected. Our data indicate that glucose is taken up by activation of GLUT4 possibly mediated by hyperglycaemia-induced activation of PKC.

Acknowledgements. This work was supported by grants from the Fortune-Programm F1284126, the German Diabetes Foundation (Deutsche Diabetes Stiftung 75/01/99) and by Roche Diagnostics, Mannheim, Germany. The authors extend thanks to Dr. M. Kellerer and Dr. R. Lammers for critical discussions and H. G. Wahl for the triglyceride determination.

\section{References}

1. Garvey WT(1992) Glucose transport and NIDDM. Diabetes Care 15: 396-417

2. Garvey WT, Huecksteadt TP, Matthaei S, Olefsky JM (1988) Role of glucose transporters in the cellular insulin resistance of type II non-insulin-dependent diabetes mellitus. J Clin Invest 81: 1528-1536

3. DeFronzo RA (1988) Lilly lecture 1987 The triumvirate: beta-cell, muscle, liver. A collusion responsible for NIDDM. Diabetes 37: 667-687

4. DeFronzo RA, Jacot E, Jequier E, Maeder E, Wahren J, Felber JP (1981) The effect of insulin on the disposal of intravenous glucose. Results from indirect calorimetry and hepatic and femoral venous catheterization. Diabetes 30: 1000-1007

5. Baron AD, Brechtel G, Wallace P, Edelman SV (1988) Rates and tissue sites of non-insulin- and insulin-mediated glucose uptake in humans. Am J Physiol 255: E769-E774

6. Gould GW, Holman GD (1993) The glucose transporter family: structure, function and tissue-specific expression. Biochem J 295: 329-341

7. Rodnick KJ, Slot JW, Studelska DR et al. (1992) Immunocytochemical and biochemical studies of GLUT4 in rat skeletal muscle. J Biol Chem 267: 6278-6285

8. Friedman JE, Dudek RW, Whitehead DS et al. (1991) Immunolocalization of glucose transporter GLUT4 within human skeletal muscle. Diabetes 40: 150-154

9. Klip A, Ramlal T, Young DA, Holloszy JO (1987) Insulininduced translocation of glucose transporters in rat hindlimb muscles. FEBS Lett 224: 224-230

10. Ramlal T, Sarabia V, Bilan PJ, Klip A (1988) Insulin-mediated translocation of glucose transporters from intracellular membranes to plasma membranes: sole mechanism of stimulation of glucose transport in L6 muscle cells. Biochem Biophys Res Commun 157: 1329-1335

11. Rett K, Wicklmayr M, Dietze GJ, Haring HU (1996) Insulin-induced glucose transporter (GLUT1 and GLUT4) translocation in cardiac muscle tissue is mimicked by bradykinin. Diabetes 45 [Suppl 1]: S66-S69

12. Marette A, Burdett E, Douen A, Vranic M, Klip A (1992) Insulin induces the translocation of GLUT4 from a unique intracellular organelle to transverse tubules in rat skeletal muscle. Diabetes 41: 1562-1569

13. Munoz P, Rosemblatt M, Testar X et al. (1995) The T-tubule is a cell-surface target for insulin-regulated recycling of membrane proteins in skeletal muscle. Biochem J 312: 393-400

14. Wang W, Hansen PA, Marshall BA, Holloszy JO, Mueckler M (1996) Insulin unmasks a COOH-terminal Glut4 epitope and increases glucose transport across T-tubules in skeletal muscle. J. Cell Biol 135: 415-430

15. Hayashi T, Wojtaszewski JF, Goodyear LJ (1997) Exercise regulation of glucose transport in skeletal muscle. Am J Physiol 273: E1039-E1051

16. Yki JH, Makimattila S (1997) Insulin resistance due to hyperglycaemia: an adaptation protecting insulin-sensitive tissues. Diabetologia 40 [Suppl 2]: S141-S144

17. Galante P, Mosthaf L, Kellerer M et al. (1995) Acute hyperglycaemia provides an insulin-independent inducer for GLUT4 translocation in $\mathrm{C} 2 \mathrm{C} 12$ myotubes and rat skeletal muscle. Diabetes 44: 646-651

18. Nolte LA, Rincon J, Wahlstrom EO, Craig BW, Zierath JR, Wallberg HH (1995) Hyperglycaemia activates glucose transport in rat skeletal muscle via a $\mathrm{Ca}(2+)$-dependent mechanism. Diabetes 44: 1345-1348

19. Haring HU, Kellerer M, Mosthaf L (1994) Modulation of insulin receptor signalling: significance of altered receptor isoform patterns and mechanism of hyperglycaemia-induced receptor modulation. Diabetologia 37 [Suppl 2]: S149-S154

20. Kawano Y, Rincon J, Soler A et al. (1999) Changes in glucose transport and protein kinase Cbeta(2) in rat skeletal muscle induced by hyperglycaemia. Diabetologia 42: 1071-1079

21. Filippis A, Clark S, Proietto J (1997) Increased flux through the hexosamine biosynthesis pathway inhibits glucose transport acutely by activation of protein kinase $\mathrm{C}$. Biochem J 324: 981-985

22. Koya D, King GL (1998) Protein kinase C activation and the development of diabetic complications. Diabetes 47: 859-866

23. Wakasaki H, Koya D, Schoen FJ et al. (1997) Targeted overexpression of protein kinase $\mathrm{C}$ beta2 isoform in myocardium causes cardiomyopathy. Proc Natl Acad Sci USA 94: 9320-9325

24. Koya D, Jirousek MR, Lin YW, Ishii H, Kuboki K, King GL (1997) Characterization of protein kinase C beta isoform activation on the gene expression of transforming growth factor-beta, extracellular matrix components, and prostanoids in the glomeruli of diabetic rats. J Clin Invest 100: 115-126

25. Berti L, Mosthaf L, Kroder G et al. (1994) Glucose-induced translocation of protein kinase $\mathrm{C}$ isoforms in rat-1 fibroblasts is paralleled by inhibition of the insulin receptor tyrosine kinase. J Biol Chem 269: 3381-3386

26. Inoguchi T, Battan R, Handler E, Sportsman JR, Heath W, King GL (1992) Preferential elevation of protein kinase C isoform beta II and diacylglycerol levels in the aorta and heart of diabetic rats: differential reversibility to glycemic control by islet cell transplantation. Proc Natl Acad Sci U S A 89: 11059-11063

27. Muller HK, Kellerer M, Ermel B et al. (1991) Prevention by protein kinase $\mathrm{C}$ inhibitors of glucose-induced insulinreceptor tyrosine kinase resistance in rat fat cells. Diabetes 40: $1440-1448$

28. Caruso M, Miele C, Oriente F et al. (1999) In L6 skeletal muscle cells, glucose induces cytosolic translocation of protein kinase $\mathrm{C}$-alpha and trans-activates the insulin receptor kinase. J Biol Chem 274: 28637-28644

29. van-de-Werve G, Zaninetti D, Lang U, Vallotton MB, Jeanrenaud B (1987) Identification of a major defect in insulin-resistant tissues of genetically obese (fa/fa) rats. Impaired protein kinase C. Diabetes 36: 310-314 
30. Khayat ZA, Tsakiridis T, Ueyama A, Somwar R, Ebina Y, Klip A (1998) Rapid stimulation of glucose transport by mitochondrial uncoupling depends in part on cytosolic $\mathrm{Ca} 2+$ and cPKC. Am J Physiol 275: C1487-C1497

31. Etgen GJ, Valasek KM, Broderick CL, Miller AR (1999) In vivo adenoviral delivery of recombinant human protein kinase C-zeta stimulates glucose transport activity in rat skeletal muscle. J Biol Chem 274: 22139-22142

32. Standaert ML, Bandyopadhyay G, Perez L et al. (1999) Insulin activates protein kinases C-zeta and C-lambda by an autophosphorylation-dependent mechanism and stimulates their translocation to GLUT4 vesicles and other membrane fractions in rat adipocytes. J Biol Chem 274: 25308-25316

33. Lawrence JCJ, Hiken JF, James DE (1990) Stimulation of glucose transport and glucose transporter phosphorylation by okadaic acid in rat adipocytes. J Biol Chem 265: 19768-19776

34. Cooper DR, Watson JE, Patel N et al. (1999) Ectopic expression of protein kinase CbetaII, -delta, and -epsilon, but not -betaI or -zeta, provide for insulin stimulation of glucose uptake in NIH-3T3 cells. Arch Biochem Biophys 372: 69-79

35. Ishizuka T, Kajita K, Miura A et al. (1999) DHEA improves glucose uptake via activations of protein kinase $\mathrm{C}$ and phosphatidylinositol 3-kinase. Am J Physiol 276: E196-E204

36. Hansen PA, Corbett JA, Holloszy JO (1997) Phorbol esters stimulate muscle glucose transport by a mechanism distinct from the insulin and hypoxia pathways. Am J Physiol 273: E28-E36

37. Guma A, Camps M, Palacin M, Testar X, Zorzano A (1990) Protein kinase C activators selectively inhibit insulin-stimulated system A transport activity in skeletal muscle at a post-receptor level. Biochem J 268: 633-639

38. Leahy JL, Cooper HE, Weir GC (1987) Impaired insulin secretion associated with near normoglycemia. Study in normal rats with 96 -h in vivo glucose infusions. Diabetes 36: 459-464

39. Hager SR, Jochen AL, Kalkhoff RK (1991) Insulin resistance in normal rats infused with glucose for $72 \mathrm{~h}$. Am J Physiol 260: E353-E362

40. Laybutt DR, Schmitz-Peiffer C, Saha AK, Ruderman NB, Biden TJ, Kraegen EW (1999) Muscle lipid accumulation and protein kinase $\mathrm{C}$ activation in the insulin-resistant chronically glucose-infused rat. Am J Physiol 277: E1070E1076

41. Ammon HP, Bacher M, Brandle WF et al. (1998) Effect of forty-eight-hour glucose infusion into rats on islet ion fluxes, ATP/ADP ratio and redox ratios of pyridine nucleotides. J Endocrinol 156: 583-590

42. Dombrowski L, Roy D, Marcotte B, Marette A (1996) A new procedure for the isolation of plasma membranes, $\mathrm{T}$ tubules, and internal membranes from skeletal muscle. Am J Physiol 270: E667-E676

43. Burdett E, Beeler T, Klip A (1987) Distribution of glucose transporters and insulin receptors in the plasma membrane and transverse tubules of skeletal muscle. Arch Biochem Biophys 253: 279-286

44. Hundal HS, Marette A, Mitsumoto Y, Ramlal T, Blostein R, Klip A (1992) Insulin induces translocation of the alpha 2 and beta 1 subunits of the $\mathrm{Na}+/ \mathrm{K}(+)$-ATPase from intracellular compartments to the plasma membrane in mammalian skeletal muscle. J Biol Chem 267: 5040-5043

45. Marette A, Krischer J, Lavoie L, Ackerley C, Carpentier JL, Klip A (1993) Insulin increases the $\mathrm{Na}(+)-\mathrm{K}(+)$-ATPase alpha 2-subunit in the surface of rat skeletal muscle: morphological evidence. Am J Physiol 265: C1716-C1722
46. Horgan DJ, Kuypers R (1988) Biochemical properties of purified transverse tubules isolated from skeletal muscle triads. Arch Biochem Biophys 260: 1-9

47. Laemmli UK (1970) Cleavage of structural proteins during the assembly of the head of bacteriophage T4. Nature 227: 680-685

48. Carr RS, Neff JM (1984) Quantitative semi-automated enzymatic assay for tissue glycogen. Comp Biochem Physiol B 77: 447-449

49. Laybutt DR, Chisholm DJ, Kraegen EW (1997) Specific adaptations in muscle and adipose tissue in response to chronic systemic glucose oversupply in rats. Am J Physiol 273: E1-E9

50. Dombrowski L, Roy D, Marette A (1998) Selective impairment in GLUT4 translocation to transverse tubules in skeletal muscle of streptozotocin-induced diabetic rats. Diabetes 47: 5-12

51. Zierath JR, He L, Guma A, Odegoard WE, Klip A, Wallberg HH (1996) Insulin action on glucose transport and plasma membrane GLUT4 content in skeletal muscle from patients with NIDDM. Diabetologia 39: 1180-1189

52. Munoz P, Rosemblatt M, Testar X, Palacin M, Zorzano A (1995) Isolation and characterization of distinct domains of sarcolemma and T-tubules from rat skeletal muscle. Biochem J 307: 273-280

53. Laybutt DR, Thompson AL, Cooney GJ, Kraegen EW (1997) Selective chronic regulation of GLUT1 and GLUT4 content by insulin, glucose, and lipid in rat cardiac muscle in vivo. Am J Physiol 273: H1309-H1316

54. Matthaei S, Stumvoll M, Kellerer M, Haring HU (2000) Pathophysiology and pharmacological treatment of insulin resistance. Endocr Rev 21: 585-618

55. Marte BM, Downward J (1997) PKB/Akt connecting phosphoinositide 3-kinase to cell survival and beyond. Trends Biochem Sci 22: 355-358

56. Bak JF (1994) Insulin receptor function and glycogen synthase activity in human skeletal muscle. Physiology and pathophysiology. Dan Med Bull 41: 179-192

57. Bossenmaier B, Mosthaf L, Mischak H, Ullrich A, Haring HU (1997) Protein kinase C isoforms beta 1 and beta 2 inhibit the tyrosine kinase activity of the insulin receptor. Diabetologia 40: 863-866

58. Kellerer M, Mushack J, Mischak H, Haring HU (1997) Protein kinase C (PKC) epsilon enhances the inhibitory effect of TNF alpha on insulin signalling in HEK293 cells. FEBS Lett 418: 119-122

59. Bollag GE, Roth RA, Beaudoin J, Mochly RD, KoshlandDE J (1986) Protein kinase C directly phosphorylates the insulin receptor in vitro and reduces its protein-tyrosine kinase activity. Proc Natl Acad Sci USA 83: 5822-5824

60. deVente JE, Carey JO, Bryant WO, Pettit GJ, Ways DK (1996) Transcriptional regulation of insulin receptor substrate 1 by protein kinase C. J Biol Chem 271: 32276-32280

61. Ganz MB, Seftel A (2000) Glucose-induced changes in protein kinase $\mathrm{C}$ and nitric oxide are prevented by vitamin E. Am J Physiol Endocrinol Metab 278: E146-E152

62. Keranen LM, Newton AC (1997) Ca2 + differentially regulates conventional protein kinase Cs' membrane interaction and activation. J Biol Chem 272: 25959-25967

63. Lin Y, Itani SI, Kurowski TG et al. (2001) Inhibition of insulin signalling and glycogen synthesis by phorbol dibutyrate in rat skeletal muscle. Am J Physiol Endocrinol Metab 281: E8-E15

64. Chiang SH, Baumann CA, Kanzaki M et al. (2001) Insulinstimulated GLUT4 translocation requires the CAP-dependent activation of TC10. Nature 410: 944-948 
65. Withers DJ, Gutierrez JS, Towery H et al. (1998) Disruption of IRS-2 causes type 2 diabetes in mice. Nature 391: 900-904

66. Jacob S, Machann J, Rett K et al. (1999) Association of increased intramyocellular lipid content with insulin resistance in lean nondiabetic offspring of type 2 diabetic subjects. Diabetes 48: 1113-1119

67. Pan DA, Lillioja S, Kriketos, AD et al. (1997) Skeletal muscle triglyceride levels are inversely related to insulin action. Diabetes 46: 983-988

68. Marshall S, Bacote V, Traxinger RR (1991) Discovery of a metabolic pathway mediating glucose-induced desensitization of the glucose transport system. Role of hexosamine biosynthesis in the induction of insulin resistance. J Biol Chem 266: 4706-4712

69. Daniels MC, Ciaraldi TP, Nikoulina S, Henry RR, McClain DA (1996) Glutamine:fructose-6-phosphate amidotransferase activity in cultured human skeletal muscle cells: relationship to glucose disposal rate in control and non-insulin- dependent diabetes mellitus subjects and regulation by glucose and insulin. J Clin Invest 97: 1235-1241

70. Buse MG, Robinson KA, Gettys TW, McMahon EG, Gulve, EA (1997) Increased activity of the hexosamine synthesis pathway in muscles of insulin-resistant $\mathrm{ob} / \mathrm{ob}$ mice. Am J Physiol 272: E1080-E1088

71. Yki JH, Daniels MC, Virkamaki A, Makimattila S, DeFronzo RA, McClain D (1996) Increased glutamine:fructose-6-phosphate amidotransferase activity in skeletal muscle of patients with NIDDM. Diabetes 45: 302-307

72. Hebert-LF J, Daniels MC, Zhou J et al. (1996) Overexpression of glutamine:fructose-6-phosphate amidotransferase in transgenic mice leads to insulin resistance. J Clin Invest 98: 930-936

73. Kolm L V, Tippmer, S Haring, HU Schleicher E (1998) Glucosamine induces translocation of protein kinase C isoenzymes in mesangial cells. Exp Clin Endocrinol Diabetes 106: $377-383$ 